\title{
PHOTOGRAMMETRY-DERIVED DIGITAL SURFACE MODEL AND ORTHOIMAGERY OF SLOPE MOUNTAIN, NORTH SLOPE, ALASKA, JUNE 2018
}

Amanda L. Willingham and Trystan M. Herriott

Raw Data File 2020-1

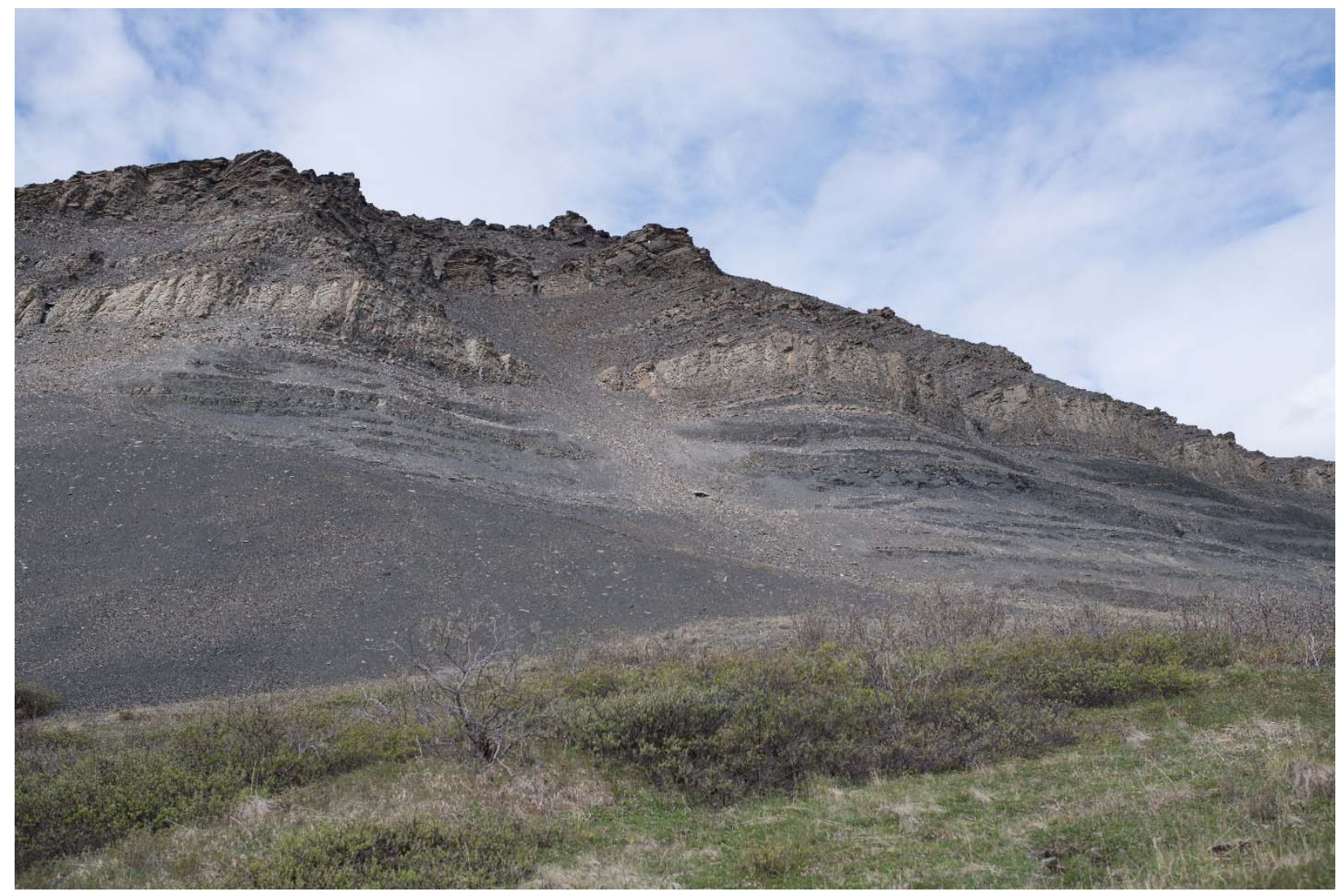

View northward of the Nanushuk and Torok Formations at Slope Mountain. Photograph by T.M. Herriott (June 24, 2018).

This report has not been reviewed for technical content or for conformity to the editorial standards of DGGS.

2020

STATE OF ALASKA

DEPARTMENT OF NATURAL RESOURCES

DIVISION OF GEOLOGICAL \& GEOPHYSICAL SURVEYS

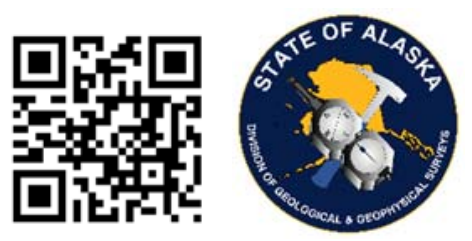


STATE OF ALASKA

Mike Dunleavy, Governor

DEPARTMENT OF NATURAL RESOURCES

Corri A. Feige, Commissioner

\section{DIVISION OF GEOLOGICAL \& GEOPHYSICAL SURVEYS}

Steve Masterman, State Geologist \& Director

Publications produced by the Division of Geological \& Geophysical Surveys are available to download from the DGGS website (dggs.alaska.gov). Publications on hard-copy or digital media can be examined or purchased in the Fairbanks office:

\section{Alaska Division of Geological \& Geophysical Surveys (DGGS)}

3354 College Road | Fairbanks, Alaska 99709-3707

Phone: 907.451.5010 | Fax 907.451.5050

dggspubs@alaska.gov | dggs.alaska.gov

DGGS publications are also available at:

Alaska State Library, Historical

Collections \& Talking Book Center

395 Whittier Street

Juneau, Alaska 99801

Alaska Resource Library and

Information Services (ARLIS)

3150 C Street, Suite 100

Anchorage, Alaska 99503

\section{Suggested citation:}

Willingham, A.L., and Herriott, T.M., 2020, Photogrammetry-derived digital surface model and orthoimagery of Slope Mountain, North Slope, Alaska, June 2018: Alaska Division of Geological \& Geophysical Surveys Raw Data File 2020-1, 9 p. http://doi.org/10.14509/30419

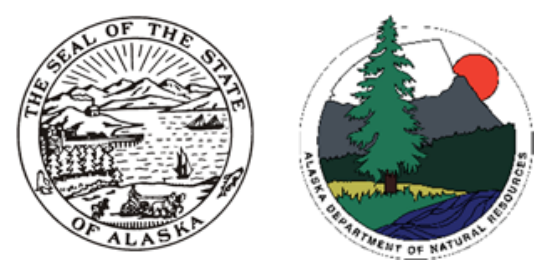




\section{PHOTOGRAMMETRY-DERIVED DIGITAL SURFACE MODEL AND ORTHOIMAGERY OF SLOPE MOUNTAIN, NORTH SLOPE, ALASKA, JUNE 2018}

Amanda L. Willingham ${ }^{1}$ and Trystan M. Herriott ${ }^{1}$

\section{INTRODUCTION}

The Alaska Division of Geological \& Geophysical Surveys (DGGS) conducted a photogrammetric survey of Slope Mountain in northern Alaska (fig. 1). The survey encompasses a well-known outcrop of significance to petroleum resources on the North Slope (for example, LePain and others, 2009). Global Navigation Satellite System (GNSS) data and aerial photographs were collected on 20-22 June 2018 and 24 and 26 June 2018, respectively. We processed these data using structure-from-motion (SfM) photogrammetric techniques (for example, James and Robson, 2012; Eltner and others, 2016) to create a digital surface model (DSM) and orthorectified aerial optical image (that is to say, orthoimagery or orthoimage) (fig. 2). This Raw Data File provides open access to, and an open end-user license for, these data products. The data files (DSM, orthoimage, and metadata) can be downloaded free of charge from the DGGS website (http://doi.org/10.14509/30419).

The goal of this data release is to provide a visual and quantitative context for the stratigraphy at Slope Mountain in support of geologic and petroleum systems studies. Slope Mountain is a road-accessible, world-class outcrop of the Cretaceous Nanushuk and Torok Formations, which form oil reservoirs in recent major petroleum discoveries on the North Slope (Houseknecht and others, 2017; Houseknecht, 2019). The Slope Mountain stratigraphy records chiefly progradational sedimentation, with depositional systems extending along depositional strike toward the recent discoveries farther north, providing a valuable outcrop analog to subsurface reservoirs (see LePain and others, 2009; Houseknecht, 2019). Within this context, DGGS recently renewed investigations at Slope Mountain, including generation of measured sections and collection of a geochronology sample suite. The DSM and othoimagery yield a threedimensional framework that complements prior detailed outcrop work and renders geologic and geographic constraints for ongoing and future studies.

${ }^{1}$ Alaska Division of Geological \& Geophysical Surveys, 3354 College Road, Fairbanks, Alaska 99709 


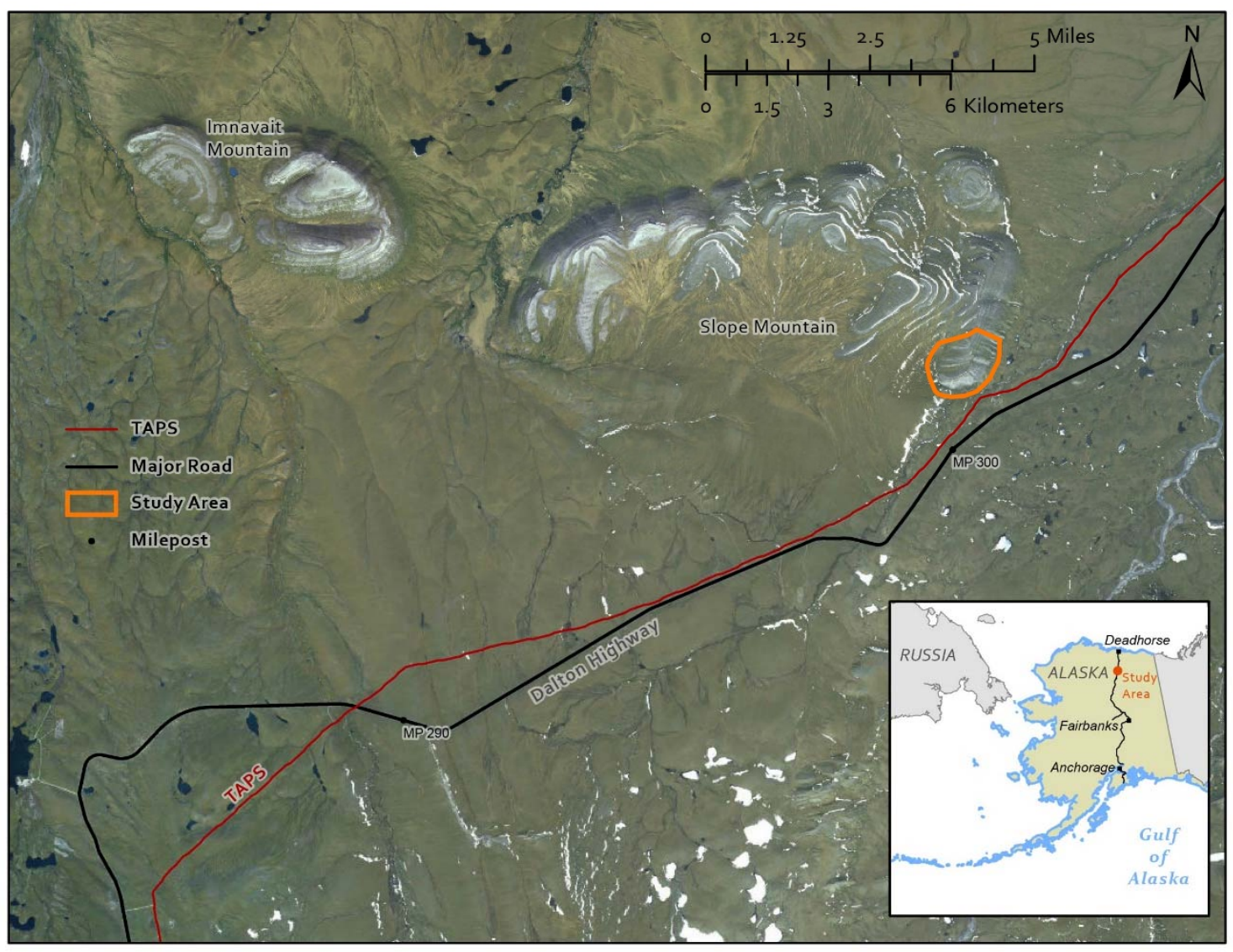

Figure 1. Study area map, showing the location of the Slope Mountain photogrammetry survey. 


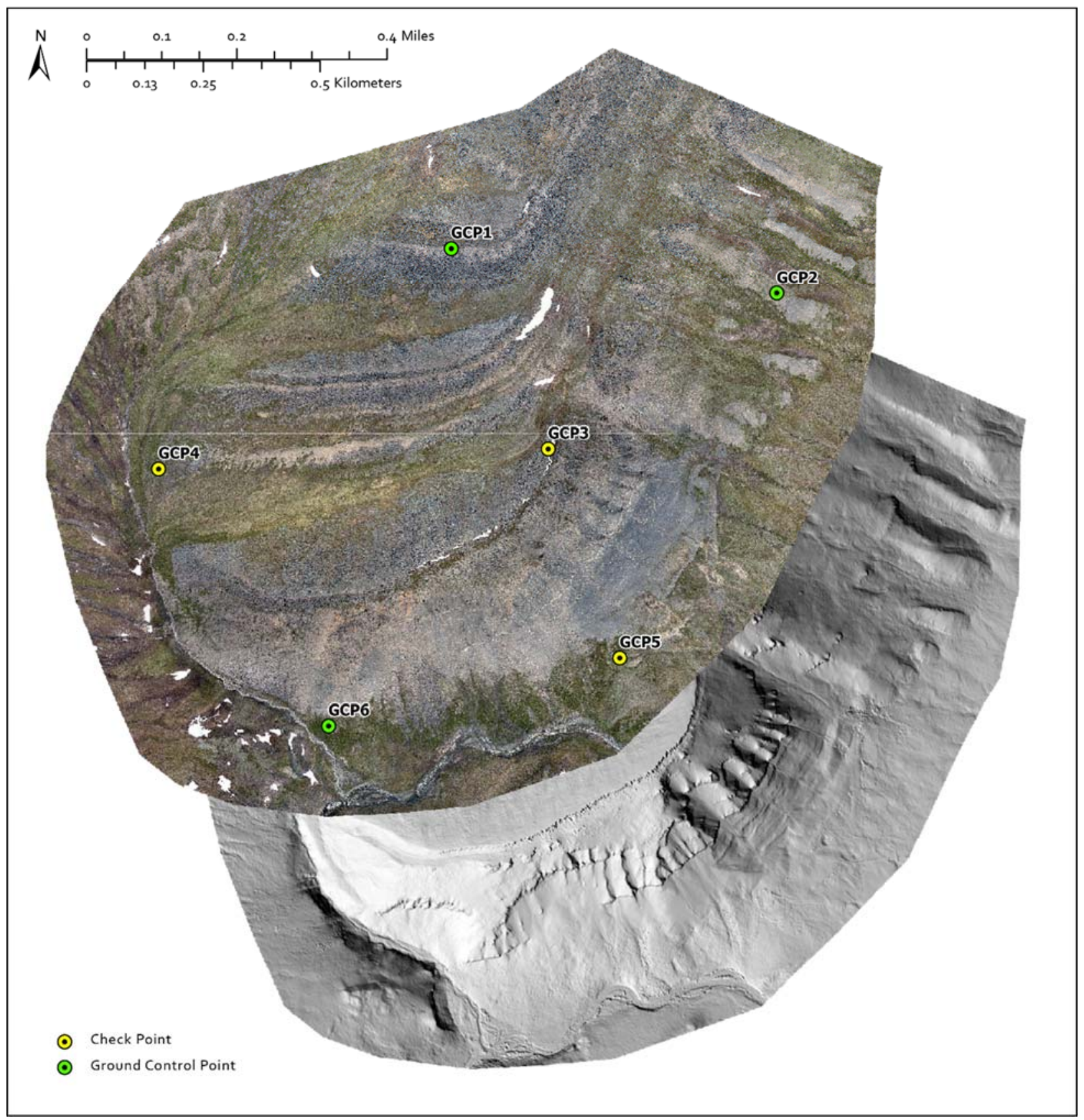

Figure 2. Orthoimage and digital surface model hillshade (this study) of the Slope Mountain area. Ground control points and checkpoints are marked and labeled. Photographs were acquired 24 and 26 June 2018.

\section{DATA ACQUISITION}

\section{Aircraft and Equipment}

Aerial photography was conducted from a Bell 206 (Jet Ranger) helicopter at an above ground-level flying height of approximately $145 \mathrm{~m}$. We employed a Nikon D850 digital single-lens 
reflex camera with a Sigma 35mm f/1.4DG HSM Art lens. The survey's design ground sample distance (GSD) is $1.8 \mathrm{~cm}$, with a survey area of approximately $2 \mathrm{~km}^{2}$. Each photograph is 45.4 megapixels (8256 x 5504 pixels); images were recorded in a 14-bit, losslessly compressed NEF (RAW) file format. Forty northeast-southwest-trending, near-nadir-view flight lines were flown with greater than $60 \%$ side-lap and $80 \%$ end-lap (figs. 3 and 4). Two additional cross-cutting nearnadir-view flight lines, as well as six oblique-view flight lines, were also flown (figs. 3 and 4), further bolstering the photographic dataset and rendering convergent imagery geometries. Select lines were re-flown to fill data gaps, as necessary. The camera was hand-held during the survey, and the shutter was triggered manually based on perceived image overlap and airspeed, resulting in 4,562 total photos.

Georeferencing described below is based on GNSS data collected on the ground during the photogrammetric campaign, as the camera itself was not fitted with a GNSS receiver. We surveyed ground targets (described below) with a Trimble R7 GNSS receiver, providing both ground control points (GCPs) - to be used in calibration-and checkpoints, which are used in the accuracy assessment of the DSM and orthoimagery. Due to poor satellite coverage in the area of the survey, long occupation times were required to yield appropriate accuracy, which led to fewer GNSS points being collected than is generally preferred. Six GNSS points were collected with the R7 as rapid static ( $<120$ minutes) or static (>120 minutes) occupations. Occupation times at GNSS points ranged from 90 to 250 minutes; the longer occupations further ensured adequate position solutions.

Each GNSS point was collected at a temporary target placed on the ground surface. At each target site, the GNSS receiver was positioned at the inside corner of two sheets of Tyvek-type material arranged in the shape of an "L"; the limbs of each target were $100 \mathrm{~cm}$ long by $28 \mathrm{~cm}$ wide and held down with landscape staples. These targets are easy to locate on the resulting orthoimagery, allowing us to readily reference our GNSS points and check the model for scale discrepancies.

\section{Weather Conditions and Flight Times}

Ground targets were deployed and GNSS data were collected between 20 and 22 June 2018. Aerial photographs were collected 24 and 26 June 2018. The first day of the photography survey (24 June 2018) had high, thin overcast conditions that were generally sunny but with variable, lower-level cloud cover, leading to some illumination discrepancies later in the day. The majority of photographs were taken this first day, between 10:55 AM and 3:12 PM. Flight line tracking and photographic coverage were estimated qualitatively by live-monitoring helicopter tracking on a tablet computer relative to planned flight lines. After the 24 June photography survey, we assessed the photographs and flight tracks and identified a few areas that would benefit from additional coverage. To address these potential data gaps, we flew a limited subset of the planned survey again on 26 June 2018, between 10:33 AM and 11:12 AM. The weather on 26 June was high-overcast and 
sunny, producing somewhat better overall lighting conditions, albeit with deeper shadows, than were encountered during the 24 June photography flight.

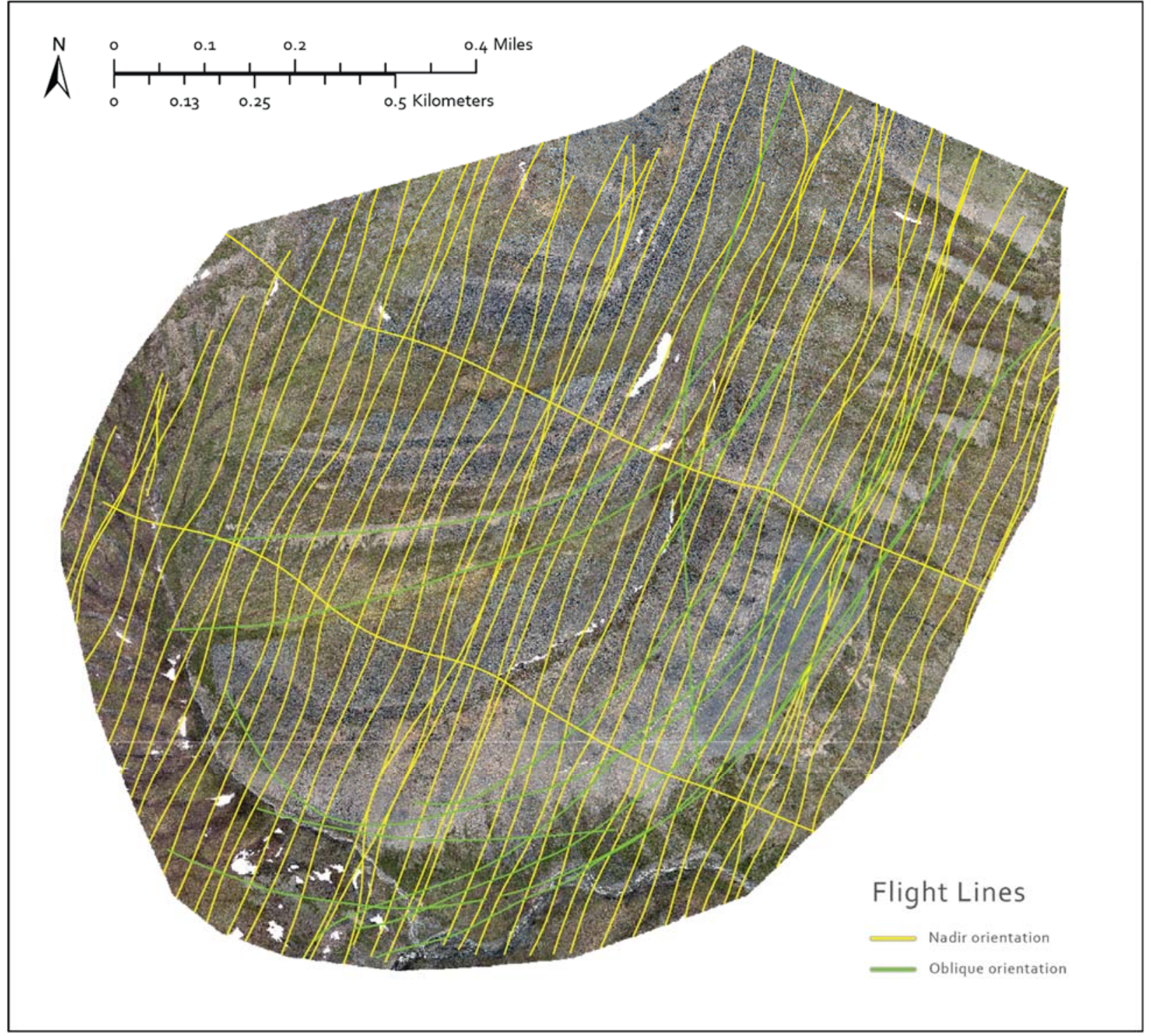

Figure 3. Flight lines included in the photogrammetry data. The camera field of view averages 23 meters wide centered on the flight line but is dependent on local terrain. Nadir or near-nadir camera views are shown in yellow; camera views oblique to the outcrop face are shown in green. Lines are solid where images were captured; re-flights are included. 


\section{PHOTOGRAMMETRY DATA PROCESSING AND PRODUCTS GNSS}

Ground control GNSS data were submitted to the National Geodetic Survey Online Positioning User Service (OPUS) for processing. OPUS generates position solutions based on the National Oceanic and Atmospheric Administration Continuously Operating Reference Station (NOAA CORS) Network. Data were processed to the North American Datum 1983 (NAD83; 2011) European Petroleum Survey Group Well Known Identification Number (EPSG) 6335 and the North American Vertical Datum of 1988 (NAVD88; Geoid12B; EPOCH 2010.00). Three of the GNSS points were used as GCPs to calibrate the DSM and orthoimagery; the remaining three points were used as checkpoints in the accuracy assessment of the data products (see below).

\section{Photography}

We oversampled the number of frames captured during the photography survey to ensure adequate photographic coverage of the study area. The total number of photographs used to build the model was necessarily reduced in Adobe Photoshop Lightroom to provide approximately $60 \%$ side-lap and $80 \%$ end-lap between adjacent flight lines and frames, respectively. The selected NEF format aerial photographs were also optimized in Lightroom to render consistent white balance and exposure parameters and minimize illumination anomalies due to variable lighting conditions during the photogrammetry survey. The selected photographic dataset ultimately comprised 2,611 photographs, which were exported from Lightroom as high-quality JPEG files and then imported into Agisoft Metashape Professional software (Version 1.5.2 build 7838) on a Windows desktop computer. Prior to alignment, image masks were developed as necessary and the photographs were georeferenced using the three GCPs (fig. 2). The photographs were processed in Metashape to edit the sparse point cloud, construct the dense point cloud, calibrate colors, and export the natural color (red, blue, green [RGB]) orthoimagery and DSM GeoTIFF files.

\section{DSM and Orthoimagery}

The DSM and orthoimagery were visually inspected for data errors such as pits, border artifacts, and shifting. The end-user should be aware that pits and peaks are present in areas of some small water bodies, such as lakes and ponds, and that DSM data are not hydro-flattened in these areas. There are also small artifacts present in some tundra-covered areas. Ragged edges of the survey with many data errors are clipped from both the DSM and orthoimagery.

Data files available for download (<http://doi.org/10.14509/30419>) are tiled DSM and RBG orthoimage GeoTIFFs. All data are projected in UTM Zone 6 North (meters) using the NAD83 (2011; EPSG 6335) horizontal datum and NAVD88 (Geoid12B; EPOCH 2010.00) vertical datum. Data product areal coverage is $2.1 \mathrm{~km}^{2}$. A single-band, 32-bit float DSM represents surface elevations of vegetation and uncovered ground surfaces in meters with a GSD of $3.8 \mathrm{~cm}$ per pixel. The "No Data" value is set to -32767 . The file employs LZ77 compression. The orthoimagery is a three-band, 8-bit unsigned GeoTIFF file. The orthoimagery GSD is $1.9 \mathrm{~cm}$ per pixel, and the "No 
Data" value is set to 256. The data products are delivered in UTM NAD83 (2011) and vertical datum NAVD88 with a GEOID correction following the latest GEOID12B for Alaska.

\section{Accuracy Assessment}

The three GNSS points designated as checkpoints assess the horizontal accuracy of the data products by comparing their GNSS-derived locations with their position on the orthoimage (fig. 2). The mean offsets (residual) are $0.62 \mathrm{~cm}$ in the $\mathrm{X}$-direction and $-1.62 \mathrm{~cm}$ in the Y-direction, with standard deviations of $32.21 \mathrm{~cm}$ (X-direction) and $97.49 \mathrm{~cm}$ (Y-direction) and mean absolute errors of $25 \mathrm{~cm}$ (X-direction) and $74.36 \mathrm{~cm}$ (Y-direction) (table 1). A horizontal transformation of $-1.3685 \mathrm{~m}$ in the $\mathrm{X}$-direction and $0.2336 \mathrm{~m}$ in the $\mathrm{Y}$-direction is applied. The vertical accuracy of the DSM is evaluated by comparing the elevation values of the same three checkpoints in the photogrammetry-derived DSM to the GNSS-derived elevation values. The mean vertical offset (Zdirection) is $-0.75 \mathrm{~cm}$, with a standard deviation of $73.66 \mathrm{~cm}$ and the mean absolute error of 55.11 $\mathrm{cm}$ (table 1). A vertical transformation of $0.5366 \mathrm{~m}$ is applied.

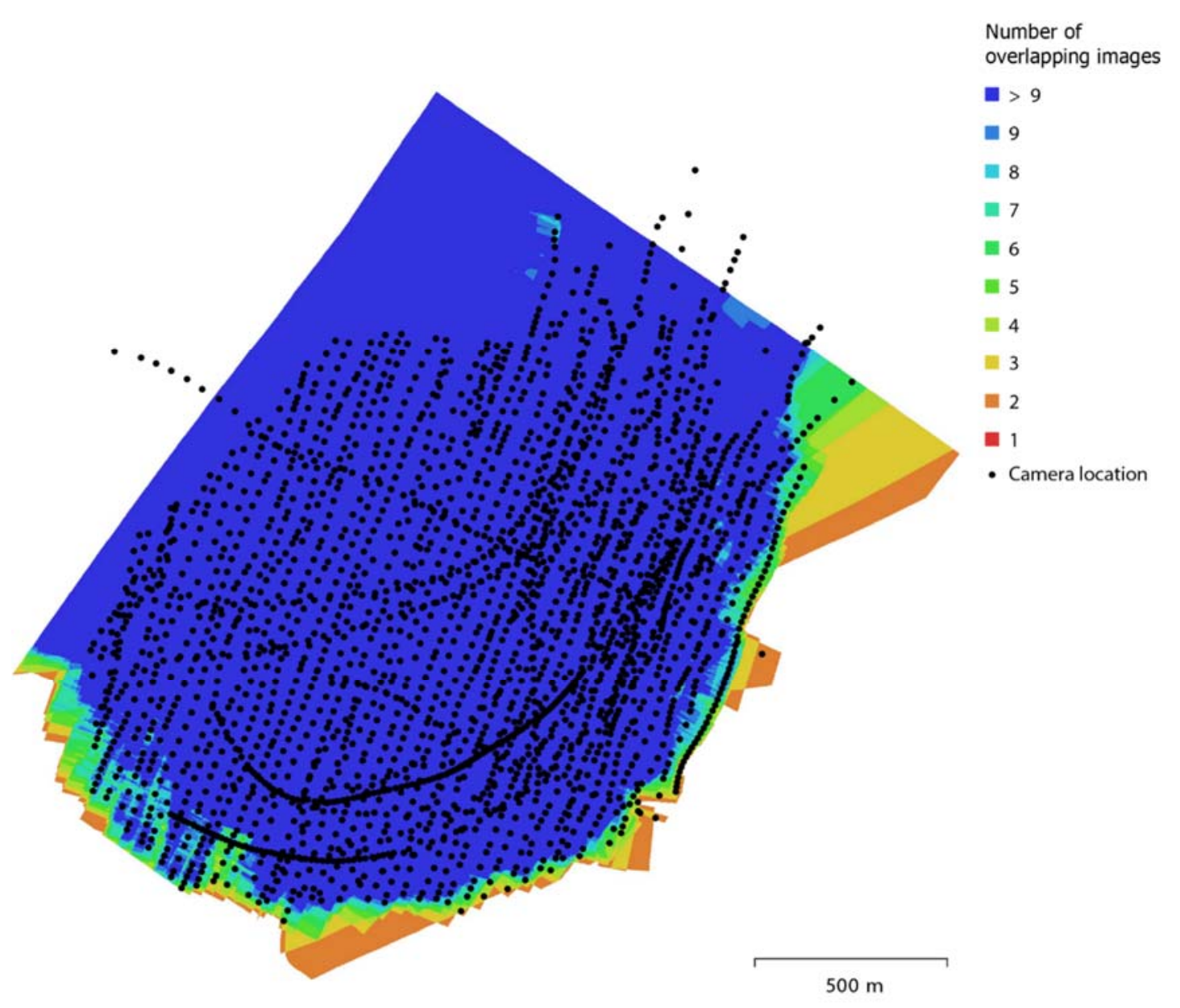

Figure 4. Camera locations and image overlap. 
Table 1. Horizontal and vertical accuracy assessment of the digital surface model and orthoimage after transformation applied, evaluated using checkpoints. Location data reported for Online Positioning User Service (OPUS) solutions of markers. Offset distances are calculated by comparing the model predicted location to the OPUS solution (surveyed) for each marker. SD = standard deviation; MAE = mean absolute error.

\begin{tabular}{|c|c|c|c|c|c|c|}
\hline Checkpoint & Easting (X) & Northing (Y) & Elevation (m) & Horizontal offset X (m) & Horizontal offset $Y(m)$ & Elevation offset $Z$ (m) \\
\hline GCP3 & 417698.197 & 7625278.151 & 942.411 & 0.1859 & 0.6076 & -0.6051 \\
\hline GCP4 & 416863.919 & 7625236.964 & 813.154 & -0.3657 & -1.1397 & 0.8154 \\
\hline \multirow[t]{5}{*}{ GCP5 } & 417851.551 & 7624828.893 & 678.231 & 0.1984 & 0.4834 & -0.2328 \\
\hline & & & Mean & 0.0062 & -0.0162 & -0.0075 \\
\hline & & & SD & 0.3221 & 0.9749 & 0.7366 \\
\hline & & & Range & 0.5641 & 1.7473 & 1.4205 \\
\hline & & & MAE & 0.2500 & 0.7436 & 0.5511 \\
\hline
\end{tabular}

Total checkpoints $=3$

Slope Mountain 2018 digital surface model cell size $=0.038 \mathrm{~m}$

Slope Mountain 2018 orthoimage cell size $=0.019 \mathrm{~m}$ 


\section{ACKNOWLEDGMENTS}

The State of Alaska funded this work. We thank helicopter pilot Tom Ratledge (Yukon Aviation) for his adaptability and precise flying during the Slope Mountain photogrammetric survey. Discussions with Katreen Wikstrom Jones and Barrett Salisbury regarding photogrammetry surveys and GNSS data processing are much appreciated. Additional support in data handling and digital products was provided by Andrew Herbst, Mike Hendricks, Kristen Janssen, and Simone Montayne.

\section{REFERENCES CITED}

Eltner, A., Kaiser, A., Castillo, C., Gilles, R., Neugirg, F., and Abellán, A., 2016, Image-based surface reconstruction in geomorphometry-Merits, limits, and developments: Earth Surface Dynamics, v. 4, p. 359-389. https://doi.org/10.5194/esurf-4-359-2016

Houseknecht, D.W., 2019, Petroleum systems framework of significant new oil discoveries in a giant Cretaceous (Aptian-Cenomanian) clinothem in Arctic Alaska: American Association of Petroleum Geologists Bulletin, v. 103, p. 619-652. http://dx.doi.org/10.1306/08151817281

Houseknecht, D.W., Lease, R.O., Schenk, C.J., Mercier, T.J., Rouse, W.A., Jarboe, P.J., Whidden, K.J., Garrity, C.P., Lewis, K.A., Heller, S.J., Craddock, W.H., Klett, T.R., Le, P.A., Smith, R.A., Tennyson, M.E., Gaswirth, S.B., Woodall, C.A., Brownfield, M.E., Leathers-Miller, H.M., and Finn, T.M., 2017, Assessment of undiscovered oil and gas resources in the Cretaceous Nanushuk and Torok Formations, Alaska North Slope, and summary of resource potential of the National Petroleum Reserve in Alaska, 2017: U.S. Geological Survey Fact Sheet 2017-3088, 4 p., https://doi.org/10.3133/fs20173088.

James, M.R., and Robson, S., 2012, Straightforward reconstruction of 3D surfaces and topography with a camera: Accuracy and geoscience application: Journal of Geophysical Research, v. 117, 17 p. https://doi.org/10.1029/2011JF002289

LePain, D.L., McCarthy, P.J., and Kirkham, R.A., 2009, Sedimentology and sequence stratigraphy of the middle Albian-Cenomanian Nanushuk Formation in outcrop, central North Slope, Alaska: Alaska Division of Geological \& Geophysical Surveys Report of Investigation 2009-1 v. 2, 76 p., 1 sheet. http://doi.org/10.14509/19761 